Tropical Journal of Pharmaceutical Research October 2015; 14 (10): 1885-1891

ISSN: $1596-5996$ (print); 1596-9827 (electronic)

(C) Pharmacotherapy Group, Faculty of Pharmacy, University of Benin, Benin City, 300001 Nigeria.

All rights reserved.

Available online at http://www.tjpr.org

Original Research Article

http://dx.doi.org/10.4314/tjpr.v14i10.21

\title{
Effect of Dual Blockade of Renin-Angiotensin Aldosterone System on Proteinuria in Patients with Diabetic Nephropathy and Advanced Azotemia
}

\author{
Hatice Odabas ${ }^{1}$, İlyas Capoglu ${ }^{2}$, Ramazan Cetinkaya ${ }^{3}$, Ali Riza Odabas ${ }^{3}$, \\ Abdullah Uyanik ${ }^{3}$ and Mustafa Keles ${ }^{3 *}$ \\ ${ }_{1}^{1}$ Department of Internal Medicine, ${ }^{2}$ Department of Endocrinology and Metabolism, ${ }^{3}$ Department of Nephrology, Faculty of \\ Medicine, Ataturk University, Erzurum, Turkey \\ ${ }^{*}$ For correspondence: Email: keles.m@gmail.com; Tel: +90-442-2317250; Fax: +90-442-2361301
}

\begin{abstract}
Purpose: To investigate the dual effect of angiotensin blockade by irbesartan and enalapril on proteinuria in diabetic patients with azotemia.

Methods: Patients with diabetes of $>5$ years duration, proteinuria at a nephrotic level and serum creatinine $>1.5 \mathrm{mg} / \mathrm{dL}$ were enrolled in the study. Forty-five enrolled patients were divided into three groups, those receiving enalapril, irbesartan, or enalapril plus irbesartan, respectively, over a period of 24 weeks. Urinary protein excretion and serum level of albumin, creatinine, potassium were measured before and after treatment

Results: In patients receiving enalapril, irbesartan, and both drugs concomitantly, mean urinary protein excretion level decreased significantly at the end of 6 months from $6.46 \pm 4.66$ to $3.36 \pm 1.60,5.89 \pm$ 5.34 to $3.22 \pm 1.72$ and $5.99 \pm 3.77$ to $2.10 \pm 2.22 \mathrm{~g} /$ day, respectively $(p=0.001)$. Decrease in proteinuria in the group receiving the combined therapy was more significant than the other two groups $(p=0.025)$. During the period of therapy, serum albumin increased and mean arterial pressure decreased significantly $(p=0.02$ and $p=0.002$, respectively) but serum creatinine and potassium and creatinine clearance values showed insignificant increases $(p=0.28$ and $p=0.57$, respectively).

Conclusion: The combined use of enalapril and irbesartan, in patients with diabetic nephropathy associated with azotemia, is more effective in decreasing proteinuria without causing any substantial increase in serum potassium levels. The combined use of these two drugs shows a more pronounced anti-proteinuric effect.
\end{abstract}

Keywords: Angiotensin-converting enzyme inhibitor, Angiotensin receptor blocker, Diabetic nephropathy, Azotemia, Proteinuria, Aldosterone, Renin, Blood pressure

Tropical Journal of Pharmaceutical Research is indexed by Science Citation Index (SciSearch), Scopus, International Pharmaceutical Abstract, Chemical Abstracts, Embase, Index Copernicus, EBSCO, African Index Medicus, JournalSeek, Journal Citation Reports/Science Edition, Directory of Open Access Journals (DOAJ), African Journal Online, Bioline International, Open-J-Gate and Pharmacy Abstracts

\section{INTRODUCTION}

Hypertension is a risk factor that exacerbates all vascular complications of diabetes and strongly influences the prognosis of the disease. Therefore, controlling concomitant hypertension in diabetic patients is at least as important as the control of diabetes [1].
In patients with diabetic nephropathy, proteinuria cannot be avoided and, if it lasts for a long period, the rapid development of end-stage renal failure is inevitable due to damaging effects of proteinuria on glomerules and tubules. In addition, hypoalbuminemia, resulting from proteinuria, is an important cause of mortality 
and morbidity in patients with diabetic nephropathy [2]. In recent years, it has been demonstrated in several studies that antihypertensive drugs belonging to the classes of angiotensin-converting enzyme inhibitors (ACEI) and angiotensin II (ATII) receptor blockers, reduce proteinuria and exert renoprotective effects, in particular, by decreasing glomerular filtration rate (GFR) as well as by lowering blood pressure [2]. Recently, combination therapy of ACEls and ATII receptor blockers has been considered in order to reduce proteinuria in patients with diabetic nephropathy. The main rationale for this combination is that the formation of ATII is not completely inhibited by ACEls and that ATII receptor blockers can completely inhibit the effects of ATII resulting from by pathways [2]. Beneficial effects expected from both single and combined use of ACEls and ATII receptor blockers in patients with diabetic nephropathy are reduced proteinuria as well as lowered blood pressure [3]. The effects of ACEls as well as ATII receptor blockers on proteinuria and renal function in patients with mild to moderate renal failure and azotemia is a recent area under focus.

The principal objective of the present study was to test whether a difference exists between ACEls and ATII receptor blockers with respect to their ability to delay impairment of renal function by reducing proteinuria in patients with diabetic nephropathy with azotemia. This study also examined the safety of combination therapy.

\section{EXPERIMENTAL}

A total of 45 patients, including 22 women and 23 men, were included in the clinical study. They were hospitalized in either the Clinics of Internal Medicine or presented to outpatient clinics of Internal Medicine of the Medical School of Ataturk University. The study was approved (2004-6/3) by the Medical School of Ataturk University Ethics Committee according to the Declaration of Helsinki and each subject gave informed consent to participate.

\section{Patient selection and study design}

Study participants had a diagnosis of diabetic nephropathy due to type 2 diabetes mellitus (DM), or were being followed for this diagnosis. Patients with creatinine levels above $1.5 \mathrm{mg} / \mathrm{dL}$ and with proteinuria of a nephrotic level (proteinuria $\geq 3.5 \mathrm{~g} /$ day) were enrolled in the study. Their average age was $52.5 \pm 4.4$ years (range: 43 - 74 years) and their duration of diabetes was $7.2 \pm 2.6(5-14)$ years. Selected demographic and clinical parameters of the 45 patients who underwent baseline testing are shown in Table I.

The patients included in the study were divided into three groups; the first group was given enalapril $10 \mathrm{mg} / \mathrm{day}$, the second group irbesartan $300 \mathrm{mg} /$ day, and the third group enalapril 10 $\mathrm{mg} /$ day plus irbesartan $300 \mathrm{mg} /$ day. Known diabetes duration and oral antidiabetic medications in use by the patients were recorded. The effects of the drugs on proteinuria, electrolytes, renal function tests and mean arterial pressure were compared. Patients without secondary hypertension, with duration of diabetes greater than five years, a serum creatinine level above $1.5 \mathrm{mg} / \mathrm{dL}$, proteinuria of nephrotic level, a body mass index below 30, and with diastolic blood pressure not exceeding 100 $\mathrm{mmHg}$ were included in the study.

\section{Blood pressure measurement}

Arterial tension values of the patients were measured with an ERKA sleeve sphygmomanometer. Patients rested 15 minutes prior to measurement. Measurements were taken twice from the right arm of sitting patients at intervals of five minutes. The results of the two measurements were averaged. Mean arterial pressure (MAP) was calculated in the patients according to the following formula: diastolic pressure + 1/3 (systolic pressure - diastolic pressure).

\section{Biochemical specimen collection}

Morning venous blood samples were taken from the patients following 10 to $12 \mathrm{~h}$ of fasting and biochemical parameters were studied. Fasting blood glucose (FBG), sodium $(\mathrm{Na})$, potassium $(\mathrm{K}+)$, uric acid (UA), blood urea nitrogen (BUN) and creatinine were routinely studied in the central biochemical laboratory of our hospital.

During the study period, relevant biochemical parameters of the blood samples and the level of proteinuria were monitored once in two months starting from day 15. Following initiation of drug treatment, renal function, especially serum electrolytes, were monitored closely. For proteinuria determination in urine, the result based on protein $(\mathrm{g} / \mathrm{dL})$ and creatinine $(\mathrm{g} / \mathrm{dL})$ values in the first morning urine sample and urinary protein/creatinine ratio $(\mathrm{U} \mathrm{P} / \mathrm{Cr})$ were considered as $\mathrm{g} / \mathrm{g}$ proteinuria. For each patient, these values were determined twice every other day and the mean of these results were taken. 


\section{Creatinine clearance and proteinuria measurement}

Estimated creatinine clearance $(\mathrm{eCrCl})$ was calculated using Cockcroft-Gault equation [(140age) $\times$ weight $/ 72 \times$ serum creatinine] $\times 0.85$ for female. The patients received a diet containing $0.8 \mathrm{~g} / \mathrm{kg}$ of protein and $100 \mathrm{mmol}$ of sodium. During the study period, therapies that might have changed the efficacy of the treatments (e.g., diuretic and albumin use) were avoided.

During the study period, biochemical blood samples and the amount of proteinuria were studied once in two months starting from day 15. Following initiation of drug treatment, renal function, especially serum electrolytes, were monitored closely. For proteinuria determination in the urine, the result based on protein $(\mathrm{g} / \mathrm{dL})$ and creatinine $(\mathrm{g} / \mathrm{dL})$ values in the first morning urine sample and urinary protein/creatinine ratio $(\mathrm{U} \mathrm{P} / \mathrm{Cr}$ ) were considered as $\mathrm{g} / \mathrm{g}$ proteinuria. For each patient, these values were determined twice every other day and the average of these results were considered.

\section{Statistical analysis}

Arithmetic means and standard deviations of the values obtained at the end of the study were calculated. These values were presented as mean \pm standard deviation. SPSS for Windows, version 11.5 (Chicago, Illinois, USA) was used for statistical analysis. In-group changes between pre- and post-treatment values were calculated separately by Wilcoxon-rank test in both groups. Post-treatment values were calculated separately by Wilcoxon-rank test in both groups. Linear regression analysis was used to determine factors affecting differences in proteinuria. age, sex, differences in MAP, systolic and diastolic blood pressure, creatinine clearance $(\mathrm{CrCl})$, serum creatinine $(\mathrm{sCr})$, potassium, sodium, albumin and medications were included as independent variables. Kruskal-Wallis variance analysis was used to determine differences in therapeutic outcomes among the three groups. Relationships between numeric variables were tested using the Spearman correlation analysis. A statistical significance level of $p<0.05$ was used in this study.

\section{RESULTS}

MAP, SBP, DBP, sCr levels, eCrCl, serum albumin levels and urinary protein/creatinine ratio, as well as age and sex distribution were not significantly different among these three groups at baseline $(p>0.05)$ (Table 1$)$.

\section{Proteinuria and serum albumin levels in the study groups}

As seen in Table II; at month six, proteinuria levels in the patients receiving enalapril, irbesartan and the combination treatment had decreased from $6.46 \pm 4.66$ to $3.36 \pm 1.60 \mathrm{~g} /$ day; $5.89 \pm 5.34$ to $3.22 \pm 1.72 \mathrm{~g} / \mathrm{day}$, and $5.99 \pm 3.77$ to $2.10 \pm 2.22 \mathrm{~g} /$ day, respectively $(p=0.001)$. When the therapeutic efficacy at month 6 was evaluated based on proteinuria levels, it was found that there was no significant difference between enalapril and irbesartan groups ( $p=$ 0.56). However, decrease of proteinuria in the group receiving combined treatment was found to be more significant than the other two groups (Kruskal-Wallis, $p=0.025$, mean differences in enalapril, irbesartan and combination groups 3.1, 2.67 and 3.89 respectively). Multinomial linear regression analysis showed no relationship between proteinuria and the level of decreases of MAP or the other investigated variables (ANOVA: $\mathrm{F}=0.996, p=0.470$ ).

Serum albumin levels in the patients receiving enalapril or irbesartan increased from $3.22 \pm 0.17$ to $3.40 \pm 0.54 \mathrm{~g} / \mathrm{dL}$ and $3.17 \pm 0.57$ to $3.42 \pm$ $0.56 \mathrm{~g} / \mathrm{dL}$, respectively, over the 6 months of the study.

Table 1: Demographic profile and clinical characteristics of patients

\begin{tabular}{lcccc}
\hline Parameter & Enalapril & Irbesartan & Combination & $P$-value \\
\hline Sex (female/male) & $8 / 7$ & $7 / 8$ & $7 / 8$ & $\mathrm{NS}$ \\
Age (years) & $51.6 \pm 4.5$ & $53.2 \pm 3.4$ & $52.7 \pm 3.8$ & $\mathrm{NS}$ \\
MAP (mmHg) & $103.53 \pm 9.04$ & $106.46 \pm 10.3$ & $105.26 \pm 4.89$ & $\mathrm{NS}$ \\
SBP $(\mathrm{mmHg})$ & $145.33 \pm 14.0$ & $146.67 \pm 14.4$ & $147.1 \pm 10.2$ & $\mathrm{NS}$ \\
DBP $(\mathrm{mmHg})$ & $84.0 \pm 9.1$ & $85.6 \pm 9.02$ & $84.33 \pm 5.6$ & $\mathrm{NS}$ \\
sCr $(\mu \mathrm{mol} / \mathrm{L})$ & $191.84 \pm 48.4$ & $197.12 \pm 66.9$ & $189.2 \pm 57.2$ & $\mathrm{NS}$ \\
eCrCl $(\mathrm{ml} / \mathrm{min})$ & $38.39 \pm 6.8$ & $38.80 \pm 11.99$ & $41.23 \pm 10.4$ & $\mathrm{NS}$ \\
Serum albumin $(\mathrm{g} / \mathrm{dL})$ & $3.22 \pm 0.17$ & $3.17 \pm 0.57$ & $3.23 \pm 0.45$ & $\mathrm{NS}$ \\
U P/Cr $(\mathrm{g} / \mathrm{g})$ & $6.46 \pm 4.66$ & $5.89 \pm 5.34$ & $5.99 \pm 3.77$ & $\mathrm{NS}$ \\
\hline
\end{tabular}

eCrCl: estimated creatinine clearance, DBP: diastolic blood pressure, SBP: systolic blood pressure, sCr: serum creatinine, MAP: mean arterial blood pressure, NS: not significant, U P/Cr: urinary protein/creatinine ratio 
These increases were statistically significant $(p=$ $0.03, p=0.02$, respectively) (Table 2). Furthermore, treatment with enalapril plus irbesartan significantly increased the serum levels of albumin $(p=0.02)$. However, no significant difference was found in the correlation analysis performed to test for a relationship between the decrease in proteinuria level and the increase in serum albumin level in the patients receiving enalapril and irbesartan $(r=-0.96, p=$ $0.56, r=0.227, p=0.16$, respectively). Similarly, the increase in serum albumin level in the group receiving combination therapy was found to be independent of proteinuria $(r=0.23, p=0.15)$.

\section{Serum creatinine, $\mathrm{CrCl}$, serum potassium and HbA1c levels}

Increases in serum creatinine and $\mathrm{CrCl}$ levels of the patients receiving enalapril, irbesartan or combination therapy of enalapril and irbesartan were not significant. Pre- and post-treatment serum potassium levels in all three groups receiving treatment remained within normal limits. No patient developed hyperkalaemia requiring interruption of the treatment. Similarly, no significant differences were found with respect to serum potassium levels $(p=0.64)$ at month six for any treatment. HbA1c levels had significantly decreased in all treatment groups $(p=0.001)$ by the end of month six (Table 2).
Systolic-diastolic blood pressure and MAP levels Significant differences were found in each of three groups (enalapril, irbesartan and combination) with respect to baseline and posttreatment systolic blood pressure values $(p=$ $0.001, p=0.006, p=0.002$, respectively) (Table $2)$. The same magnitude of systolic blood pressure decrease was observed in all three groups (no significant difference between groups, $p=0.421)$.

Differences were found in each of three groups with respect to baseline and post-treatment diastolic blood pressure values $(p=0.07,0.028$, 0.02 for enalapril group, inbesatan and combination therapy group, respectively; Table 2). The same magnitude of diastolic blood pressure decrease was observed in all three groups (no significant difference between groups, $p=0.528)$.

A significant decrease in MAP became apparent during month two, and this decrease continued until the end of the study. In the group receiving enalapril, there was a significant decrease $(p=$ 0.002 ) in the MAP values at month 6 when compared to pre-treatment values. Also MAP values significantly decreased in the groups receiving irbesartan $(p=0.002)$ and enalapril plus irbesartan $(p=0.002)$ at month six when compared to pre-treatment values (Table 2).

Table 2: Prior and post-treatment results for the study groups

\begin{tabular}{|c|c|c|c|c|c|c|c|c|c|}
\hline \multirow[t]{2}{*}{ Variable } & \multicolumn{3}{|c|}{ Enalapril } & \multicolumn{3}{|c|}{ Irbesartan } & \multicolumn{3}{|c|}{ Combination } \\
\hline & Prior & Post- & $\begin{array}{l}P \text { - } \\
\text { value }\end{array}$ & Prior & Post- & $\begin{array}{l}P \text { - } \\
\text { value }\end{array}$ & Prior & Post- & $\begin{array}{l}P \text { - } \\
\text { value }\end{array}$ \\
\hline $\begin{array}{l}\text { MAP } \\
(\mathrm{mmHg})\end{array}$ & $103.53 \pm 9.0$ & $92.0 \pm 9.0$ & 0.002 & $106.46 \pm 10.3$ & $93.9 \pm 11.2$ & 0.002 & $105.26 \pm 4.89$ & $91.26 \pm 5.82$ & 0.002 \\
\hline $\begin{array}{l}\text { SBP } \\
(\mathrm{mmHg})\end{array}$ & $145.33 \pm 14.0$ & $131.33 \pm 7.1$ & 0.001 & $146.67 \pm 14.4$ & $133.31 \pm 9.5$ & 0.006 & $147.1 \pm 10.2$ & $130.08 \pm 6.32$ & 0.002 \\
\hline $\begin{array}{l}\text { DBP } \\
(\mathrm{mmHg})\end{array}$ & $84.0 \pm 9.1$ & $81.0 \pm 8.2$ & 0.07 & $85.6 \pm 9.02$ & $83.6 \pm 6.11$ & 0.028 & $84.33 \pm 5.6$ & $80.09 \pm 6.92$ & 0.02 \\
\hline U P/Cr (g/g) & $6.46 \pm 4.66$ & $3.36 \pm 1.60$ & 0.001 & $5.89 \pm 5.34$ & $3.22 \pm 1.72$ & 0.001 & $5.99 \pm 3.77$ & $2.10 \pm 2.22$ & 0.001 \\
\hline $\begin{array}{l}\text { sAlb } \\
(g / d L)\end{array}$ & $3.22 \pm 0.17$ & $3.40 \pm 0.54$ & 0.03 & $3.17 \pm 0.57$ & $3.42 \pm 0.56$ & 0.02 & $3.23 \pm 0.45$ & $3.51 \pm 0.72$ & 0.02 \\
\hline $\begin{array}{l}\mathrm{sCr} \\
(\mu \mathrm{mol} / \mathrm{L})\end{array}$ & $191.84 \pm 48.4$ & $195.36 \pm 51.0$ & 0.5 & $197.12 \pm 66.9$ & $202.4 \pm 62.5$ & 0.22 & $189.2 \pm 57.2$ & $203.28 \pm 44.9$ & 0.28 \\
\hline $\begin{array}{l}\text { eCrCl } \\
\text { (ml/min) }\end{array}$ & $38.39 \pm 6.8$ & $37.7 \pm 6.7$ & 0.06 & $38.80 \pm 11.99$ & $37.5 \pm 10.6$ & 0.11 & $41.23 \pm 10.4$ & $40.76 \pm 10.0$ & 0.57 \\
\hline $\mathrm{sK}^{+}(\mathrm{mEq} / \mathrm{L})$ & $4.90 \pm 0.51$ & $5.06 \pm 0.58$ & 0.16 & $4.67 \pm 0.66$ & $4.88 \pm 0.69$ & 0.27 & $4.66 \pm 0.54$ & $4.711 \pm 0.56$ & 0.70 \\
\hline $\begin{array}{l}\mathrm{HbA1c} \\
(\%)\end{array}$ & $8.90 \pm 0.60$ & $7.10 \pm 0.22$ & 0.001 & $8.8 \pm 0.73$ & $7.21 \pm 0.36$ & 0.001 & $9.02 \pm 2.7$ & $7.32 \pm 1.17$ & 0.001 \\
\hline
\end{tabular}




\section{DISCUSSION}

Several studies have demonstrated that ATII receptor blockers and ACEls have antiproteinuric and renoprotective effects in both diabetic and non-diabetic patients. It was seen that anti-proteinuric effects in both groups were not significantly different when anti-proteinuric effects in the patients receiving enalapril and irbesartan were compared. The decrease in proteinuria in the third group receiving combination therapy was found to be significant compared to other groups.

A number of studies have found that in patients with diabetic nephropathy, ACEI and ATII receptor blockers delay end-stage renal failure by slowing renal failure progression. Studies on rennin-angiotensin-aldosterone have shown that ATII is formed in several ways other than through ACE, suggesting that ACEls fail to inhibit the rennin-angiotensin-aldosterone system $[1,3]$. Furthermore, ACE is not a very specific enzyme and it has several substances other than ATI including bradykinin, substance $P$ and neurokinins. ACEls increase the levels of such substances [3-5]. Thus, ATII antagonists seem to provide a more specific effect than ACE inhibitors by blocking the effects of ATII at the receptor level.

The main rationale for using an ACE inhibitor combined with an ATII receptor blocker is the ACE escape mechanism, wherein ATII and aldosterone levels return to pre-treatment levels despite continuous treatment with ACEls. Combining two drugs reduces the effect of the ACE escape mechanism while maintaining the effect of ACE inhibitors on bradykinin cleavage $[2,6]$. In both clinical and experimental administrations, additional effects of dual blockage have been observed on both blood pressure and neuro-humoral activation. This shows that such combination therapy inhibits the effects of ATII more prominently than fixed dose treatment with ACEls. This study demonstrates that combination therapy reduces proteinuria to a greater extent compared with treatment with enalapril or irbesartan alone. Corresponding decreases in serum albumin and proteinuria levels were observed in the patients. This may be due to a decrease in protein loss in urine. Dietary factors may have also contributed to this outcome.

In the present study, it was observed that a decrease in proteinuria was independent of a decrease in MAP. The fact that a decrease in proteinuria becomes apparent in later periods of treatment, whereas a decrease in blood pressure become apparent at the end of the first month of treatment, suggests that a decrease in MAP is independent of a decrease in proteinuria [7-9]. Whereas a decrease in blood pressure can occur over the short-term (within hours), it takes about 1 month for an anti-proteinuric effect to reach a maximal level. Hypertension leads to renal damage and this worsens hypertension. Now it is possible to break this vicious cycle by means of an early and efficient anti-hypertensive treatment. Such a treatment could be used in several nephropathies, especially in diabetic nephropathy.

In a study of enalapril involving patients with nondiabetic nephropathy, Apperloo et al [10] noted that arterial blood pressure was reduced significantly from $150 \pm 22 / 91 \pm 13 \mathrm{mmHg}$ to $132 \pm 17 / 79 \pm 10 \mathrm{mmHg}$. In a study on hypertensive patients with nephropathy, Gansevoort et al gave patients either 50 or 100 $\mathrm{mg}$ losartan once daily. A decrease in mean blood pressure $24 \mathrm{~h}$ after the administration of the dose was found to be $9.2 \%$ in the $50 \mathrm{mg}$ losartan group and $10.9 \%$ in the $100 \mathrm{mg}$ losartan group. In that study, a significant difference was not found with respect to patients receiving 100 or $50 \mathrm{mg}$ losartan [11].

In this study, no significant difference was found between both groups in pre-treatment and posttreatment serum creatinine levels. At the same time, no significant differences were found among any of the treatments with respect to serum creatinine levels. Reversible acute renal failure may occur on occasion in patients with diabetic nephropathy in whom proteinuria is at the nephrotic level. However, neither acute renal failure nor unexpected extreme increases in creatinine levels due to treatment were recorded in any patient during our follow-up observations. Doubling of the serum creatinine level in 583 patients with nephropathy was found to be less common in the group receiving ACEI compared to the group receiving a placebo in the "Angiotensin-Converting-Enzyme Inhibition in Progressive Renal Insufficiency Study" [12] An important conclusion from that study is that ACEls do not have a renoprotective effect in patients whose daily proteinuria is below $2 \mathrm{~g}$. A renoprotective effect is observed when daily proteinuria is equal to or more than three $g$ [13].

In patients in whom diabetic nephropathy developed and GFR was reduced, it is likely that hyperkalaemia may develop due to blockage of 
RAAS during treatment with both ACEls and ATII receptor blockers. There is a higher risk of hyperkalaemia in patients with more prominent nephropathy and lower GFR $[14,15]$. Interstitial nephritis is commonly observed in such patients during course of diabetic nephropathy further increases the risk of hyperpotassemia by means of hyporenninemic hypoaldosteronism. Using ACEls and ATII receptor blockers requires close laboratory and clinical monitoring of these patients. In the Irbesartan Diabetic Nephropathy Trial, it was observed that only $2 \%$ of cases resulting from use of the drug had hyperkalemia enough to stop irbesartan [16].

In a placebo-controlled study by Andersen et al [17] using $10 / 20 \mathrm{mg}$ of enalapril and $50 / 100 \mathrm{mg}$ of losartan in patients with type I diabetes mellitus, it was reported that serum potassium levels increased significantly compared to baseline levels in both treatments with 10 and 20 $\mathrm{mg}$ of enalapril. Serum potassium levels did not change significantly in the groups given losartan. While serum potassium levels increased in the patients receiving enalapril, it was emphasized that the difference was not significant [17]. In a study by Gansevoort et al involving a group of hypertensive patients, it was reported that serum potassium levels increased more prominently as a result of administration of $100 \mathrm{mg}$ of losartan compared to $50 \mathrm{mg}$ of Losartan. This difference was reported to be clinically significant [11]. In The Losartan Heart Failure Survival Study-ELITE trial completed in 1997, the difference between pre-treatment and post-treatment serum potassium levels was significant in patients taking captopril, and no significant difference was found in the group receiving losartan [18].

In the present study, no significant differences were found among the three groups in terms of pre-treatment and post-treatment serum potassium levels. At the same time, dangerous hyperkalemia requiring discontinuation of treatment did not develop in any patient. Reasons for no development of hyperkalemia may include restricting food enriched in potassium in the diet and relatively not high doses of the drugs given. In the cases reported in the literature, serious hyperkalemia developed when rather higher doses of drugs were given such as $20 \mathrm{mg}$ of enalapril or $100 \mathrm{mg}$ of Losartan. Again, if these patients are receiving potassium-sparing diuretics, the resulting increases in potassium levels may be dangerous [11].
The significant difference found between pretreatment and post-treatment $\mathrm{HbA} 1 \mathrm{c}$ levels in this study may have been the result of several factors, including the close monitoring of patients, dietary adjustments and efficient insulin therapy.

\section{CONCLUSION}

Administration of enalapril, irbesartan and a combination of these two drugs to patients with diabetic nephropathy presenting with apparent proteinuria and azotemia results in apparent antiproteinuric effects. This effect is independent of the anti-hypertensive effects of the drugs. No serious side effects due to treatment were observed. They are therefore an efficient option for the treatment of proteinuria and hypertension in patients presenting with apparent proteinuria.

\section{REFERENCES}

1. Lasaridis $A N$, Sarafidis $P A$. Diabetic nephropathy and antihypertensive treatment: what are the lessons from clinical trials? Am J Hypertens 2003; 16: 689-697.

2. Luno J, Praga $M$, de Vinuesa SG. The reno-protective effect of the dual blockade of the renin angiotensin system (RAS). Curr Pharm Des 2005; 11: 1291-1300.

3. Yildirim T, Arici M. Renin-angiotensin-aldosterone system blockade in chronic kidney disease. Turkiye Klinikleri $J$ Int Med Sci 2007; 3: 6 -68.

4. Dzau VJ, Re R. Tissue angiotensin system in cardiovascular medicine. A paradigm shift? Circulation 1994; 89: 493-498.

5. Griendling KK, Murphy TJ, Alexander RW. Molecular biology of the renin-angiotensin system. Circulation 1993; 87: 1816-1828.

6. Lewis EJ, Hunsicker LG, Bain RP, Rahde RD. The effect of angiotensin converting enzyme inhibition on diabetic nephropathy. N Engl J Med 1993; 329: 14561462.

7. Maki DD, Ma JZ, Louis TA, Kasiske BL. Long-term effects of antihypertensive agents on proteinuria and renal function. Arch Intern Med 1995; 155: 10731080.

8. Maschio G, Alberti D, Janin G, Locatelli F, Mann JF, Motolese M, Ponticelli C, Ritz E, Zucchelli P. Effect of the angiotensin-converting-enzyme inhibitor benazepril on the progression of chronic renal insufficiency. The Angiotensin-Converting-Enzyme Inhibition in Progressive Renal Insufficiency Study Group. N Engl J Med 1996; 334: 939-945.

9. Nakamura $T$, Ushiyama $C$, Suzuki $S$, Shimada $N$, Sekizuka K, Ebihara I, Takahashi Y, Tanaka A, Koide $H$. Comparison between the angiotensin II receptor antagonist candesartan cilexetil and the angiotensinconverting enzyme inhibitor trandolapril in 
microalbuminuria of patients with early diabetic nephropathy. Nephron 2000; 86: 247-248.

10. Apperloo AJ, de Zeeuw D, de Jong PE. Short-term antiproteinuric response to antihypertensive treatment predicts long-term GFR decline in patients with non-diabetic renal disease. Kidney Int 1994; (suppl 4): 174-178.

11. Gansevoort RT, de Zeeuw D, Shahinfar S, Redfield A, de Jong $P E$. Effects of the angiotensin II antagonist losartan in hypertensive patients with renal disease. $J$ Hypertens Suppl 1994; 12: 37-42.

12. Maschio G, Alberti D, Locatelli F, Mann JF, Motolese M, Ponticelli C, Ritz E, Janin G, Zucchelli P. Angiotensinconverting enzyme inhibitors and kidney protection: the AIPRI trial. The ACE Inhibition in Progressive Renal Insufficiency (AIPRI) Study Group. J Cardiovasc Pharmacol 1999; 33(Suppl 1): 16-43.

13. Ruggenenti $P$, Perna A, Zoccali C, Garini G, Zoccali $C$, Salvadori M, Scolari F, Schena FP, Remuzzi G. Renoprotective properties of ACE-inhibition in nondiabetic nephropathies with non-nephrotic proteinuria. Lancet 1999; 31: 354-359.

14. Cooper M, Boner G. Dual blockade of the reninangiotensin system in diabetic nephropathy. Diabet Med 2004; 21(Suppl 1): 15-18.
15. Jennings $D L$, Kalus JS, Coleman Cl, Manierski C, Yee J. Combination therapy with an ACE inhibitor and an angiotensin receptor blocker for diabetic nephropathy: a meta-analysis. Diabetic Medicine 2007; 24: 486-493.

16. Pohl MA, Blumenthal S, Cordonnier DJ, De Alvaro F, Deferrari G, Eisner G, Esmatjes E, Gilbert RE, Hunsicker LG, de Faria JB, et al. Independent and additive impact of blood pressure control and angiotensin II receptor blockade on renal outcomes in the irbesartan diabetic nephropathy trial: clinical implications and limitations. J Am Soc Nephrol 2005; 16: 3027-3037.

17. Andersen S, Tarnow L, Rossing P, Hansen BV, Parving $H H$. Renoprotective effects of angiotensin II receptor blockade in type 1 diabetic patients with diabetic nephropathy. Kidney Int 2000; 57: 601-606.

18. Pitt B, Poole-Wilson P, Segal R, Martinez FA, Dickstein K, Camm AJ, Konstam MA, Riegger G, Klinger GH, Neaton J, et al. Effects of losartan versus captopril on mortality in patients with symptomatic heart failure: rationale, design, and baseline characteristics of patients in the Losartan Heart Failure Survival StudyELITE II. Card Fail 1999; 5: 146-154. 